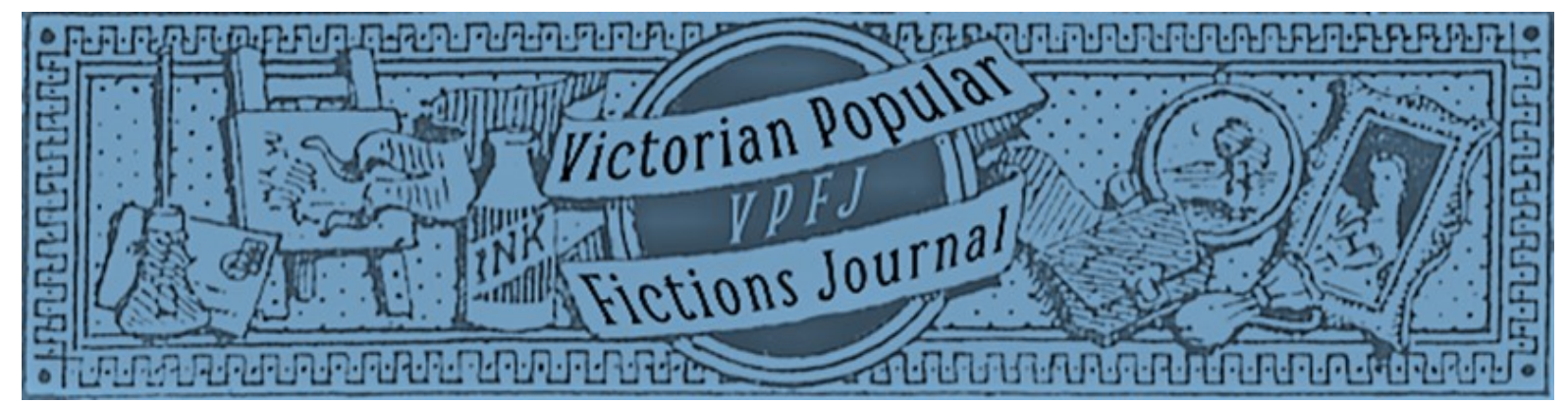

\title{
Oscar Wilde's Misattributions: A Legacy of Gross Indecency
}

\author{
Katerina García-Walsh
}

\begin{abstract}
Drawing on correspondence and periodical advertising as well as paratextual and bibliographic detail, this paper compares editions of the three most prominent texts falsely associated with Oscar Wilde: The Green Carnation (1894), an intimate satire on Wilde's relationship with Lord Alfred Douglas actually written by Douglas' friend Robert Smythe Hichens; "The Priest and the Acolyte" (1894), a paedophilic story written by John Francis Bloxam and presented as evidence against Wilde during his libel trial and then privately reprinted; and the erotic novel Teleny (1893), which is still attributed to Wilde today. His name appeared in tandem with these novels over the course of a century, linking him further with sex and scandal. Two separate editions of Teleny in 1984 and 1986 feature introductions by Winston Leyland and John McRae, respectively justifying Wilde's authorship and describing the work as likely a round-robin pornographic collaboration between Wilde and his young friends. By recognising and exposing these cases of literary impersonation, we can amend Wilde's legacy.
\end{abstract}

\section{Keywords}

Oscar Wilde; The Green Carnation; "The Priest and the Acolyte"; Teleny; Misattribution

Date of Acceptance: 8 December 2021

Date of Publication: 17 December 2021

Double Blind Peer Reviewed

\section{Recommended Citation:}

García-Walsh, Katerina. 2021. "Oscar Wilde's Misattributions: A Legacy of Gross Indecency." Victorian Popular Fictions, 3.2: 189-208. ISSN: 2632-4253 (online) DOI: https://doi.org/10.46911/ PYIV5690

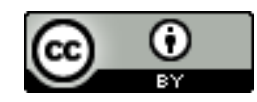

This work is licensed under a Creative Commons Attribution 4.0 International License. 


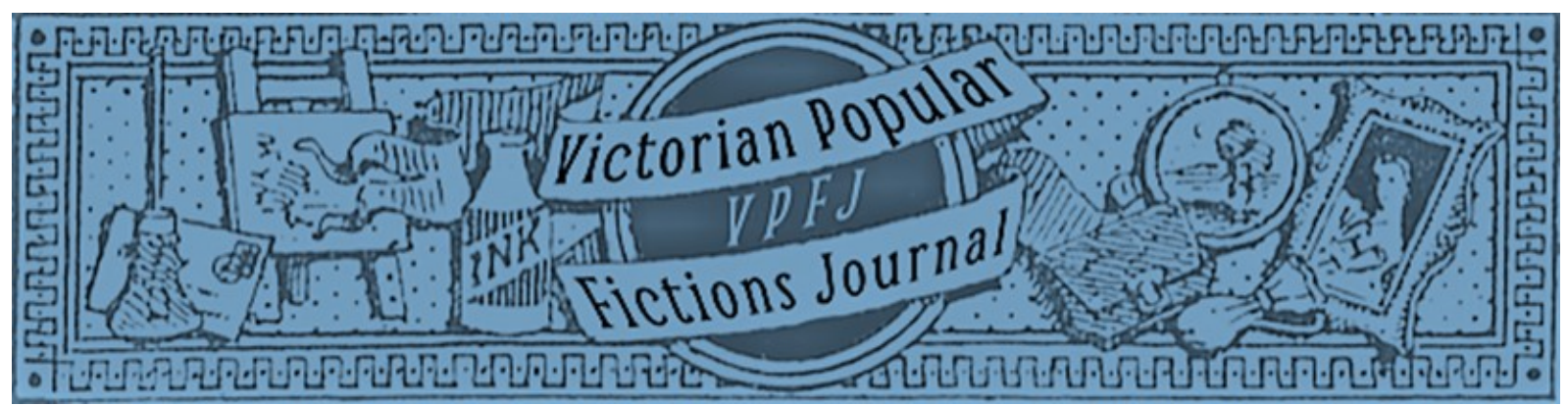

\title{
Oscar Wilde's Misattributions: A Legacy of Gross Indecency
}

\author{
Katerina García-Walsh
}

\section{Introduction}

When Oscar Wilde wrote De Profundis from the depths of Reading Gaol in 1897, he bitterly recalled the short story "The Priest and the Acolyte," which, initially misattributed to him, had a pivotal role in the libel trial that would imprison him. The story features a paedophilic Anglican priest who seduces a fourteen-year-old boy, ending with a ritualistic double-suicide when their paedophilic relationship is discovered. "The Priest and the Acolyte" (1894), which would follow Wilde for at least half a century, was not the only tale of a suggestive nature to contribute in a significant way to a hypersexualisation of the author's legacy. Before his trials, The Green Carnation (1894) would seem to "out" him through parody of his relationships and, after his death, Teleny (1893) would acquire fame through its connection to Wilde. ${ }^{1}$ This paper traces the history of these three most prominent texts of "gross indecency" misattributed to Wilde.

As has been amply discussed in the critical literature, the well-known events of Wilde's trials occasioned a scandal that would haunt his private life and public literary persona thereafter. In February 1895, the Marquis of Queensberry's ongoing opposition to his son's relationship with Oscar Wilde reached a crisis when he left a card at the author's club, the Albemarle, addressed "To Oscar Wilde posing as a Somdomite [sic]." In previous months,

\footnotetext{
${ }^{1}$ This paper focuses on texts for which Wilde was the misattributed author. As Rod Boroughs (1995) discusses, the publisher Charles Carrington also falsely attributed 1902 translations of Petronius' Satyricon and Ce qui ne meurt pas (printed in English as What Never Dies) by Jules Barbey d'Aurevilly (1883) to Oscar Wilde, under his pseudonym Sebastian Melmoth.

${ }^{2}$ For more information, see Richard Ellmann's biography (1987: 412).
} 
Wilde's notoriety has already been heightened by the circulation of a dangerously intimate and suggestively erotic satire on his relationship with Douglas, The Green Carnation. Goaded by his lover, Queensberry's son Lord Alfred Douglas, Wilde soon after initiated a libel case against Queensberry. During this initial trial, further information regarding Wilde's relationships with men surfaced and Queensberry was acquitted, which rendered Wilde liable for the defence's legal fees, leading to his ruin and imprisonment.

The devastating financial toll of this trial was minor compared to Wilde's subsequent arrest for "gross indecency" under the Labouchere Amendment of 1885. While he was awaiting his second trial, Queensberry demanded the nearly seven hundred pounds of costs awarded him. Wilde's wife, Constance, besieged by creditors and unable to pay the rent on their Tite Street home, left London with their two sons. The unpaid rent triggered a Sheriff's bankruptcy sale on 24 April of Wilde's possessions, including his books and personal effects. Though Wilde's friends, including Robert Ross, who would later become his literary executor, attempted to recover his unpublished manuscripts before this by breaking and entering, they were unable to find the missing works. Later at the Sheriff's auction, Ross witnessed the disarray and overt thefts of the writer's belongings: some items were pocketed while others, such as personal letters between Wilde and Constance, vanished. The sale fetched less than three hundred pounds, falling short of covering Wilde's debts. Queensberry petitioned for the remainder and Wilde was declared bankrupt. ${ }^{3}$ By May 1895, two further trials concluded with a sentence of unusual severity: two years of hard labour (Ellmann 1987: 434-49). When he was released in 1897, impoverished and estranged from his family, he spent the remaining three years of his life in declining health, dying a near-penniless expatriate in Paris in 1900.

While the aforementioned texts misattributed to Wilde could be imagined as numbering among the manuscripts lost in the Sheriff's sale or penned afterwards out of financial necessity, they were, in fact, all first published before Wilde's trials. Nonetheless, the manuscripts lost in auction alongside the prevalence of piracies in the years following the author's death would come to cast a shadow of confusion over Wilde's authentic literary legacy. His fall from grace constituted an opportunity, after his death, for authors and publishers who used Wilde's fame to promote and disseminate their texts. Alongside Ross' efforts as literary executor, Christopher Sclater Millard would issue works on Wilde under the pseudonym Stuart Mason from 1907 until his early death in $1927 .{ }^{4}$ Millard's research culminated in his Bibliography of Oscar Wilde (1914), an extensive catalogue including, additionally, descriptions of Ross's legal actions against publishers who pirated Wilde's texts and detailed notes dispelling misattributions of authorship. In retracing the history of these three provocative misattributions, I hope to highlight their enduring impact on Wilde's person and literary canon both during his life and well after his death.

\footnotetext{
${ }^{3}$ For more information, see, for instance, Mead (2015).

${ }^{4}$ Although Millard publishes on Wilde under his pseudonym, Mason, this article will refer to him as Millard throughout for consistency. For a more detailed history of Wilde's bibliographies in the twentieth century, see Stratford (1995) amended with a note by Murray (1996).
} 


\section{The Green Carnation}

On 15 September 1894, an anonymous publication emerged titled The Green Carnation; its protagonists, Esmé Amarinth and Lord Reginald Hastings, were transparent parodies of Wilde and Douglas. ${ }^{5}$ Wilde's biographer, Richard Ellmann discusses how the green carnation, a flower chemically tinted and therefore symbolic of artifice conjoined with nature, became emblematic of Wilde's aestheticism and public persona (1987: 344-5). Ellmann further notes the particular light in which The Green Carnation depicted Wilde and Douglas' relationship:

[The novel] pretended to be a parody, but it was more like a documentary. Its fictional veneer is thin and there could be no doubt of the identities of Lord Reggie and Mr Amarinth. The moral of the book [is demonstrated through] Lord Reggie's slavish imitation of Amarinth's conversational leads. In the process he ceases to be himself [...] The book bore out the Queensberry version of the relationship.

The Green Carnation not only implied proscribed intimacy between its two protagonists, but promoted an image of Wilde/Amarinth as a seducer who controlled and manipulated Douglas/Reggie. The realism and familiarity with which The Green Carnation reproduced Wilde's conversations with Douglas narrowed the list of likely authors to Wilde's more intimate circle with Wilde himself as the rumoured author. Wilde wrote a letter to his friend and author Ada Leverson to ask her indirectly if she had been responsible for the text. In this letter, Wilde describes The Green Carnation as a novel by a "doubting disciple" of his who had penned a "false gospel" (Wilde 2000: 615). Despite the dangers of such a publication, Wilde initially approached the text with mild amusement. In 1894, Wilde had little reason to consider the book a direct threat to himself, notwithstanding the unflattering light it cast upon his private life. Wilde discovered the novel's true author, Robert Smythe Hichens, within a matter of days. Hichens recounts in a 1949 edition of The Green Carnation that Wilde had sent him "a bogus telegram about it though it came out anonymously, showing that he had guessed I had written it." 6 Ellmann notes that Hichens, a friend of Douglas, had accompanied him and other young men on a trip to Egypt where Wilde, absent from the company, was nonetheless a common topic of conversation: "Hichens listened attentively, and made notes for The Green Carnation" (1987: 392). Ellmann further speculates that Hichens may have relied on Max Beerbohm's assistance, sending him the manuscript of The Green Carnation in summer 1894 to perfect its depiction of Wilde and Douglas' relationship (399-400). With Wilde's suspicions confirmed, he wrote again to Ada Leverson, admitting he "did not think [Hichens] capable of anything so clever. It is such a bore about journalists" (Wilde 2000: 615). The novel may have seemed too clever and literary for Hichens, but Wilde's qualified praise of The Green Carnation quickly soured once he was proposed as the novel's likely author, a rumour that reached The Pall Mall Gazette on 27 September 1894:

\footnotetext{
${ }^{5}$ Merlin Holland and Rupert Hart-Davis note the unambiguous clarity of these references in The Complete Letters of Oscar Wilde (Wilde 2000: 615n).

${ }^{6}$ Cited by Holland and Hart-Davis (Wilde 2000: 616n).
} 
We can excuse [The Green Carnation] only on the supposition that he [Wilde] wrote it himself. A man may certainly burlesque himself if he like; in fact, it would be a clever thing to do. Has Mr. Wilde done it?

(cited in Millard 1967: 167-8) ${ }^{7}$

Though the article does not claim Wilde's authorship categorically, this rumour threatened him regardless of its truth. Had he not written The Green Carnation as a self-satire, then its true author may be revealing private information about Wilde's relationships to the general public. Wilde, however, was quick to reply to this allegation, adamantly denying authorship in the following letter:

To the Editor of the Pall Mall Gazette

1 October

Worthing

Sir, Kindly allow me to contradict, in the most emphatic manner, the suggestion made in your issue of Thursday last, and since then copied into many other newspapers, that I am the author of The Green Carnation.

I invented that magnificent flower. But with the middle-class and mediocre book that usurps its strangely beautiful name I have, I need hardly say, nothing whatsoever to do. The flower is a work of art. The book is not.

I remain, sir, your obedient servant

OSCAR WILDE

(Wilde 2000: 617)

Holland and Hart-Davis include this in Wilde's Complete Letters, but note that the original of this particular letter does not exist and that the above is found in reproductions only. Further, they reference a 1987 article by scholar Genevieve Brennan, who questions the letter's authenticity, suggesting instead that it may be the work of A.J.A. Symons. ${ }^{8}$ However, the letter was published in the Pall Mall Gazette on 2 October 1894 under the title "The Green Carnation." Holland and Hart-Davis, while mentioning that Wilde was in the habit of writing notes "to the owners of firms on their own paper when he called at their offices and did not find them" and offering three such examples (Wilde 2000: 378, 527, 568), nonetheless advise caution with this particular item (Wilde 2000: 617n). The Pall Mall Gazette letter is often cited as the evidence that The Green Carnation was misattributed to Wilde. ${ }^{9}$ Moreover, Walter Edwin Ledger, a collector who assisted Ross and Millard in their efforts to compile Wilde's bibliography, obtained a clipping of the letter from The Pall Mall Gazette and glued it into his own edition of The Green Carnation as a makeshift foreword, labelling its date in pencil (Appendix 1). While the absence of the original text among Wilde's personal

\footnotetext{
${ }^{7}$ The article's title, "Satire À La Mode," likely refers to a series of six paintings by William Hogarth created in 1743 and titled Marriage à-la-mode, which were satires of the upper class. In the citation, the addition of [The Green Carnation] is my change; the clarification of [Wilde] is Millard's addition. Millard's Bibliography was originally issued under the pseudonym Mason. The edition I have accessed and will therefore cite in this article is a 1967 facsimile from the Wilde Collection of University College, Oxford.

${ }^{8}$ Holland and Hart-Davis describe A. J. A. Symons as a forger, informed by Brennan's (1987) descriptions of his work with counterfeit documents in the 1920s (Wilde 2000: 617n).

${ }^{9}$ Millard copies it into his Bibliography (1967: 234); Ellmann cites it in his biography (1987: 401); and an auction description of an edition of unknown origin of The Green Carnation selling for $£ 250$, which finally found its way to the Magdalen College, Oxford collection, references it (tucked between the first two pages of Hichens 1894-d).
} 
effects may seem initially suspect, its confirmed publication in 1894 along with Hichens' later admission of authorship legitimises the letter. The Pall Mall Gazette's suggestive wording in their original article would have placed Wilde in a quagmire: he could either ignore the misattribution and accept the novel as an excusable self-satire or refute authorship at the risk of transforming the novel's contents into an inexcusable, damning challenge to his personal reputation. Wilde's response, therefore, reveals his decision to prioritise his legacy as a writer over his personal and material safety as a queer man. At this point Wilde may have been more concerned with literary misattribution in itself, rather than anticipating his future exposure.

Indeed, Wilde was concerned by the misattribution to himself of what he viewed as aesthetically inferior texts regardless of any erotic or salacious content. In November 1894, Wilde wrote to his publisher, Arthur L. Humphreys, regarding the publication of Oscariana, a book of aphorisms. "After the Green Carnation," Wilde writes, "this book of 'real Oscar Wilde' should be refined and distinguished: else, it will look like a bit of journalism" (Wilde 2000: 624). Wilde echoes here his earlier letter to Leverson in which he referred to Hichens as a mere journalist whose novel had been unexpectedly clever - perhaps literary. The novel's misattribution to Wilde produces anxieties over his own wit and wisdom reduced to mediocre journalism. The desire to distance himself from The Green Carnation thus becomes a goal of Oscariana.

Wilde's frustration with The Green Carnation's misattribution was likely heightened by a similar, albeit more politically neutral occurrence less than a fortnight before the Pall Mall Gazette's article. Millard in the Bibliography describes a six-stanza poem attributed to Wilde and titled "The Shamrock," which was published in The Weekly Sun on 5 August 1894 (1967: 163). When the same poem was reproduced in The New York Sun on 19 August, the Reverend William J. McClure recognised it and wrote a letter to the editor indicating that the poem, with some minor variations, had already been printed in the Cork Weekly Herald during the 1880s. The New York Sun printed McClure's letter on 23 August and later, on 31 August, published a short article demanding an explanation from The Weekly Sun. The response from The Weekly Sun came on 16 September with the title "Is it Plagiarism? What Saith Mr. Oscar Wilde?" As Wilde explained in an impassioned letter to the Pall Mall Gazette, he was "enraged" by the accusation of plagiarism over a poem that he had not written and regarded as "doggerel verses." Wilde used his letter as an opportunity to express irritation regarding "The Ethics of Journalism" in which he discussed "the low standard of ethics" of "modern journalists." Within a week, on 23 September, The Weekly Sun issued a correction, identifying the poem's author as Helena Callanan (Millard 1967: 163-5). Wilde's frustration with journalistic standards over this accusation of plagiarism colours his description of Hichens as a journalist in his letter to Leverson, which Wilde wrote around the same day as The Weekly Sun's retraction, 23 September. The misattribution of The Green Carnation, so soon after "The Shamrock" misattribution and subsequent accusation of plagiarism, contextualises Wilde's denial of authorship to the Pall Mall Gazette.

Unlike "The Shamrock," however, The Green Carnation's misattribution was not limited to journalistic rumour. Instead, as the Pall Mall Gazette implied, its effect was more overtly pernicious. Angela Kingston in Oscar Wilde as a Character in Victorian Fiction, writes that "any damage to Wilde's career done by" earlier fictions satirising him as a character "pales in comparison to that brought about by [...] Robert Hichens' The Green Carnation." The "facetious portrait was taken by many to be true to life" and "his reading public were shocked by the novel and were not slow to react; The Green Carnation prompted an immediate 
succès de scandale upon its release" (Kingston 2007: 138-45). Indeed, Hichens issued anonymous second and third editions of The Green Carnation on 4 October and 24 October 1894, reflecting the book's unexpected success. ${ }^{10}$ By the second edition, Wilde had already identified Hichens as author and publicly disclaimed his own alleged authorship. It was not until May 1896, while Wilde was serving time in Reading Gaol, that The Green Carnation was again reprinted finally naming Hichens as its author.

Even once Hichens appears as the author, these reprints draw from the paratextual format of the 1894 editions in which the publisher's name and identity replace the absent author. The title page of the 1894 editions is paired with a typically Decadent Japonesque illustration printed in lime green and yellow that serves as the cover in the cheaper 'ornamental wrappers' version of 1894 (Hichens 1894-a). Opposite this, the anonymous texts feature the title, its place in the publisher's Pioneer Series and the publisher's name. The cloth bound exterior repeats the same data: the title on the top right corner of the front cover and spine, "The Pioneer Series" centred on the back cover and Heinemann's name along the bottom of the spine (Hichens 1894-d and 1894-e, see Appendix 1). In the absence of an author, this decision to grant the publisher primacy is perhaps unsurprising. However, the 1896 edition, which includes Hichens' name on the title page, nonetheless sports a cover identical to its predecessors, still with no indication of authorship. Privately rebound copies of The Green Carnation from 1894 often contain even less information, and, in the case of one rebound 1894 text, tucked into its pages are two sales descriptions advertising the book as either by Oscar Wilde or connected to him, with no mention of Hichens as its author (Appendix 2). In the first of these two items, a sales card for Roy Bleiweiss, Wilde's name is mentioned in association with the text. While this may refer to the history of the book as a parody of Wilde's personal life, further clarification is provided on the bookseller's catalogue, as the novella is credited with having "helped make [Wilde] famous," without any mention of Hichens. In the second, from a more contemporary auction that lists Wilde and Hichens side by side in its bibliographic heading, the description calls the text a "notorious satire" and references Wilde's letter in the Pall Mall Gazette disavowing authorship. Yet this description only alludes to Hichens, omitting his name from the description and reporting that the book has an "ownership signature on the front wrapper." The signature found on the front wrapper is Hichens', relegating him to the status of owner rather than author. While Hichens' name appears in the bibliographic heading (albeit secondary to Wilde), the description speaks of Wilde for eight lines of text, without mention of Hichens' name, and only alluding to Hichens in the last line as owner (inside Hichens 1894-c, see Appendix 2). Both sales descriptions promote the books' connection to Wilde with an eye to selling them at a higher price. This association with a more recognisable author is common practice, as collectors like Edwin Ledger were, in fact, interested in books both by and linked to Wilde. Though these bibliographic conventions for organising catalogues are useful for prospective patrons and researchers alike, in the case of texts such as The Green Carnation, they have contributed, even if unintentionally, to visibility of Wilde's name over Hichens's. Indeed, it was not until a year before Hichens' death in 1949 that he authorised another edition of The Green Carnation, through Unicorn Press, this time writing an introduction in which he explicitly discusses his authorship.

\footnotetext{
${ }^{10}$ Millard's Bibliography includes this information (1967: 168) and it is also catalogued in a list of reprints in the 1986 edition of The Green Carnation.
} 
The Green Carnation's fame, it would seem, stems primarily if not exclusively from its association with Wilde. Ellmann suggests malicious intent with this publication, writing that Max Beerbohm, who had early access to the book's manuscript, "could not have been totally unaware of the risks" and perhaps "awaited with unconscious excitement the removal of the master [Wilde] from the London scene" (1987: 400). His evidence for this is a letter from Beerbohm to Reggie Turner, a friend who accompanied Douglas and Hichens on their trip to Egypt, from 12 August 1894 in which he describes a fictional account that foresees Wilde's arrest. Ellmann additionally cites a letter dated to April or May 1895 and addressed to Leverson that says he "look[s] forward eagerly to the first act of Oscar's new Tragedy. But surely the title Douglas must have been used before," implying that his relationship with Douglas, which The Green Carnation describes, would mark Wilde's downfall (1987: 400). While Ellmann attributes this letter to Beerbohm, Horst Schroeder, in his Additions and Corrections to Richard Ellmann's Oscar Wilde, notes this letter was actually written by Aubrey Beardsley, making its connection to The Green Carnation more tenuous (2002:151). ${ }^{11}$ Nonetheless, Ellmann rightly mentions that Queensberry himself read The Green Carnation and was not amused; it may well have contributed to Queensberry's view that Wilde was corrupting his son (1987: 400). I argue that the misattribution intensified its public perception as an autobiographical text rather than a work of complete fiction. The Green Carnation coupled with the trade practices that allowed its misattribution to Wilde consequently played a pivotal role in the well-known events to come.

\section{"The Priest and the Acolyte"}

Between 6 and 11 April 1895, following Wilde's arrest, a penny pamphlet emerged summarising "The Life of Oscar Wilde as Prosecutor and Prisoner." A second edition of the same pamphlet came out before the end of April advertising information on "The Life and Doings of Oscar Wilde, Further Startling Developments" ("Just Out" and "Second Edition"). Mentions of a publication titled The Chameleon filled pages five through seven of both pamphlets. ${ }^{12}$ The Chameleon was an Oxford undergraduate publication published on 1 December 1894. Douglas was a contributor and friend of the magazine's editor, John Francis Bloxam, an Oxford undergraduate at Exeter College. Through Douglas, Wilde sent Bloxam a series of paradoxical aphorisms in November 1894, which would become the first page of the publication, printed as "Phrases and Philosophies for the Use of the Young." The Chameleon featured prominently in Wilde's libel trial not for the aphorisms he wrote, however, but for another story of which Queensberry disapproved and initially took to be Wilde's work. The story in question, "The Priest and the Acolyte," was published anonymously as the ninth contribution of this first and only issue of The Chameleon, describing a priest's paedophilic relationship with an altar boy. When they are discovered, the priest poisons the sacramental wine, ending the tale in murder-suicide. The content of this story invites no ambiguity.

\footnotetext{
${ }^{11}$ See also Beardsley (1970: 82).

${ }^{12}$ The pamphlets were only fourteen and fifteen pages long, respectively.

13 These aphorisms were originally intended for the Saturday Review, but Douglas and Bloxam convinced Wilde to submit them to the Oxford magazine (Wilde 2000: 702).
} 
Much later, in 1923, Millard acquired a letter from Bloxam to Charles Kains Jackson, poet and leader of the gay men's Uranian Movement, who is also listed as a contributor to The Chameleon. ${ }^{14}$ In the letter, dated 18 November 1894, Bloxam describes meeting with Wilde and George Ives, during which the title The Chameleon was decided and Wilde promised Bloxam the aphorisms. ${ }^{15}$ When Bloxam speaks in his letter to Jackson of the success of "my own little story" with The Chameleon's publishers, Gay \& Bird, we can infer that he is alluding to "The Priest and the Acolyte" (Appendix 3). Ellmann claims that Bloxam showed Wilde his story in their first meeting and cites an entry from George Ives' journal in which Ives writes that Wilde "was encouraging Bloxam to publish" the tale (1987: 403-4). A few days after this meeting, Wilde, in a letter to Leverson, refers to a "story" which he found lacking in "nuance," and though "it is at moments poisonous," it was no more than "interesting" (Wilde quoted in Ellmann 1987: 404). Wilde, however, recalls the meeting rather differently in De Profundis:

One day you [Lord Alfred Douglas] come to me and ask me as a personal favour to you, to write something for an Oxford undergraduate magazine, about to be started by some friend of yours of whom I have never heard in all my life, and knew nothing at all about. To please you - what did I not do always to please you? - I sent him a page of paradoxes destined originally for the Saturday Review. A few months later I find myself standing in the dock of the Old Bailey on account of the character of the magazine. It forms part of the Crown charge against me. I am called upon to defend your friend's prose and your own verse. The former I cannot palliate: the latter I, loyal to the bitter extreme, to your youthful literature as to your youthful life, do very strongly defend, and will not hear of your being a writer of indecencies. But I go to prison, all the same, for your friend's undergraduate magazine and the "Love that dares not tell its name."16

(2005: 60)

Wilde only contributed his aphorisms to The Chameleon, but it was his association with the paedophilic story that featured as crucial evidence against him. Millard notes in his Bibliography that though The Chameleon was intended to have three issues per year, provided to subscribers at 15 shillings per annum, the publication ceased after the first number when on 29 December 1894 the writer Jerome K. Jerome reviewed it on page 241 of his journal To-Day (1967: 14). Ellmann describes Jerome's 'review' as a "call for police action" in light of the supposedly criminal, or gay, contents of the publication (1987: 404). The Chameleon was discontinued but not without having caused irreparable harm.

Word of Wilde's association with "The Priest and the Acolyte" circulated quickly. Even worse than The Chameleon's already damning effect was that Bloxam had the story printed privately and anonymously in 1904 or 1905 "for Presentation only." 17 Its stapled and taped 8 vo binding with cardboard cover was delicate and in unique dimensions $(21.75 \times 17.5 \mathrm{~cm})$ with oversized margins (text printed on area of $14.5 \times 5.75 \mathrm{~cm}$ ) and a flimsy length of a total forty-six pages. In other words, while these clandestinely-printed editions, likely produced for a low value, made it difficult for copies of the text to survive, they were also much easier to

\footnotetext{
${ }^{14}$ Millard forwarded this letter to Ledger, who added it to his collection. See Appendix 3.

${ }^{15}$ It is unclear from Bloxam's writing if "we decided" includes Wilde or refers only to Bloxam and Ives.

${ }^{16}$ Douglas also contributed to the same issue of The Chameleon "Two Loves" that obliquely defended homosexual love (the "Love that dares not tell its name" to which Wilde refers at the end of this passage). These poems were brought up in Wilde's libel trial.

${ }^{17}$ Though the book states "1894" as its publication date, Peter Mendes in Clandestine Erotic Fiction in English 1800-1930 (1993) notes that the edition was likely created in 1905.
} 
inconspicuously roll up under a coat or hide between other books. ${ }^{18}$ Although this edition omits the author's name, Walter Edwin Ledger's bibliographic notes refer to an accompanying prospectus in which the publication is listed as "BY | OSCAR WILDE." ${ }^{19}$ Ledger bristles over the "unscrupulous people" who "had not the impudence" to place Wilde's name "on the title page of the book itself" but nonetheless continue to advertise it as Wilde's own creation (Ledger, 1-2). This private edition extended "The Priest and the Acolyte's" reach well beyond The Chameleon.

In subsequent years, Wilde's association with "The Priest and the Acolyte," even as its alleged author, continued to frustrate Millard, whose scholarship aimed to rescue Wilde's reputation and restore his works. On 27 April 1905, he writes to Ledger criticising "W. R.," most likely the artist Walter Graham Robertson, for perpetuating the falsehood that Wilde wrote "The Priest and the Acolyte" (Millard, Letter 27 April 1905). On 12 March 1906, he writes to Ledger again regarding further claims that Wilde had authored "The Priest and the Acolyte," this time in Edward William Pitcher's bibliographic catalogues of Wilde's works and, consequently, by Clement King Shorter in the periodical The Sphere, which Shorter edited from 1900 until his death in 1926 (Millard, Letter 12 March 1906). Frustrated by the recurrence of this misattribution, Millard issued his own edition of "The Priest and the Acolyte" prefaced with an "Introductory Protest" aiming to refute any association with Wilde:"

So many copies of "The Priest and the Acolyte" have been sold by unscrupulous publishers and booksellers under the implication that it is the work of Oscar Wilde that it has been thought good to issue this edition with the object of putting an end, once and for all, to the possibility of purchasers being misled as to the authorship. The story was originally published in The Chameleon [... and the] author of the story was an undergraduate at Oxford, "an insufficiently birched school-boy," as he has recently been described, and he alone was responsible for the contents of the magazine which he edited. At the time of the trial of Lord Queensberry for libel a few months later it was attempted to show that Oscar Wilde not only approved of the theme of the story, but that he was actually a party to the publication of it [...] The simplest way of showing what Oscar Wilde really thought of the story is to quote what he said when examined in Court on the subject.

(1907: 5-7)

Millard then spends the remainder of his introduction relating the trial's proceedings until he feels confident that "What is stated above ought to be sufficient, once and for all, to dissociate the name of the author of 'Salomé' and 'Lady Windermere's Fan' from the story reprinted in the following pages" (1907: 25). Unfortunately, that was not the case, and the misattributions persisted. The text's fame and resultant reprintings were due to its association with Wilde.

While, arguably, Millard's "Introductory Protest" is not perfectly transparent, given that he omits Bloxam's name (most likely to protect him from prison), he clearly states that the author of "The Priest and the Acolyte" was the editor of The Chameleon. Nonetheless, this partial omission in Millard's introduction led Edouard Roditi in his 1947 biography of Oscar Wilde to attribute the "semi-pornographic tale [to] a vague disciple whom he had never met," possibly a misquoting of Wilde's writing in De Profundis (4). However, Roditi later on creates suspense in his biography by claiming that "Wilde's unwillingness to name this sin

\footnotetext{
${ }^{18}$ Despite the fragile structure of this private edition, Ledger obtained a copy for five shillings, which is the source for this information (Bloxam 1894).

${ }^{19}$ A copy of this can be consulted in the Thomas Fisher Rare Book Library of the University of Toronto.

${ }^{20}$ Though there were only 500 copies printed of Millard's edition, Ledger acquired two, his main copy with Millard's autograph as "Stuart Mason" for 5 shillings (Bloxam 1907-a) and his less valued "duplicate" priced at only 2s. 6d. (Bloxam 1907-b).
} 
[homosexuality] in Dorian Gray makes one all the more sceptical of his [denial of] authorship of "The Priest and the Acolyte"" (121). That is, Roditi implies that because Wilde's description of Platonic love was euphemistic due to the legal and institutional homophobia of the time, his testimony was therefore untrustworthy when denying authorship of "The Priest and the Acolyte." After entertaining this possibility at some length, Roditi finally decides that Wilde's libel trial "proved conclusively that he had not written [it], nor even met its author, an obscure Oxford undergraduate" (121). Suddenly, and with no previous mention of the true author's full name, Roditi describes the text as "Bloxham's [sic] sexually and religiously Satanic or perverse story" (172). Roditi turns from rejecting Wilde's authorship of the text, to entertaining the doubt, to once more rejecting the idea but without clearly explaining Bloxam's relationship with The Chameleon. Ultimately, Roditi's rhetorical decisions in this biography profit from the sensationalism of Wilde's association and alleged authorship. Roditi criticises other existing biographies of Wilde "generally as sensational and unreliably biased," suggesting his own, albeit disorienting, is at least more correct than other publications in circulation at that time (242).

John G. Nelson in Publisher to the Decadents details the work of publisher Leonard Smithers who, on the one hand, we have to thank for printing "The Ballad of Reading Gaol" during Wilde's lifetime, but who, on the other hand, then famously went on to make a career out of pirating Wilde's works. Nelson describes Smithers' association between 1900 and 1907 with the London bookseller and printer Alfred E. Cooper who, through the 1890s, had "been involved with the printing, distributing, and, at times, publishing of works of erotica" (2000: 264). In 1905, Smithers published, with Cooper as printer, a pirated edition of "The Priest and the Acolyte," which further drove Millard to reprint the text with his Introductory Protest two years later. Gregory Mackie in his article on "Publishing Notoriety: Piracy, Pornography, and Oscar Wilde" describes Smithers and Cooper's piracy of "The Priest and the Acolyte" as "deliberately misattributed to Wilde" (2004: 988). ${ }^{21}$

More recently, Mackie's Beautiful Untrue Things (2019) assiduously distinguishes between misattributions such as "The Priest and the Acolyte" and forgeries, which are falsely and intentionally produced as the work of a given author. Mackie recognises that there is a certain ambiguity when misattribution and forgery "could produce similar effects" and notes, therefore, that Robert Ross "and his colleagues" were uninterested in the differentiation between these categories (2019: 35-6). Ross, Millard and Ledger protectively treat misattributions as motivated by unscrupulous intent, especially when there are clear financial benefits to a publisher, printer or bookseller. Mackie correctly notes that their primary concern is precisely the effect on Wilde's reputation. By contrast, he views forgeries as embroiled in the creation of a literary afterlife, an act of 'retelling' that, like fanfiction, remains creatively alive. While this is an important point, as the present article is concerned with works that had a direct impact on Wilde's life, I am forced to return to the importance of effect. During Wilde's life,

\footnotetext{
${ }^{21}$ Nelson and Mackie both discuss how Smithers and Cooper continued to pirate Wilde's works including Lady Windermere's Fan and Salomé in 1904, issuing them under fictional imprints titled "The Maturin Press" and "Melmoth and Co." Both of these names reference the pseudonym used by Wilde in his last days in Paris: Sebastian Melmoth. Wilde plucked the pseudonym from Melmoth the Wanderer, written by his great uncle Charles Robert Maturin (Nelson 2000: 264; Mackie 2004: 983).
} 
The Green Carnation gained autobiographical weight through its misattribution, 'outing' his relationship with Lord Alfred Douglas. His association, meanwhile, with "The Priest and the Acolyte" served as evidence in his trial, connecting Wilde's person with the destructive paedophilia of the story's plot. These particular misattributions, even if less intentional than outright forgeries, nonetheless serve as reminders that Wilde's life was fraught with the reality of navigating systemic homophobia.

\section{Teleny and Other Legacies}

While both The Green Carnation and "The Priest and the Acolyte" had a clear effect on Wilde's reputation during life, Teleny, which was first published in 1893 and later reprinted by Smithers as part of the Erotika Biblion Society in 1899, did not gain notoriety until much later, when it became more overtly associated with Wilde. ${ }^{22}$ Smithers worked with Harry Sidney Nichols, who specialised in printing erotica, to produce this "homoerotic novel whose author was rumoured to be Wilde" (Mackie 2004: 988). In his prospectus for Teleny, Smithers advertised the work as "undoubtedly, the most powerful and most cleverly written erotic Romance that has appeared in the English language during recent years" written by "a man of great imagination" and spiced by "the culture of its author's style," only implicitly Wilde (quoted in Nelson 2000: 36). Nelson notes that as early as 1910, Smithers' prospectus to Teleny, implying Wilde's authorship, directly led occultist and writer Aleister Crowley to refer to "Wilde in "Teleny" in his list of homosexual works in Scented Garden of Abdullah the Satirist of Shiraz (2000: 361). It was not until 1934, however, that Teleny was explicitly attributed to Wilde. Charles Hirsch, a Frenchman who set up a bookshop, his Libraire Parisienne, in London and specialised in the printing and dissemination of bilingual erotic works (Setz 2012: vii), issued a French translation of Teleny with an introductory "Notice Bibliographique." Hirsch claims that his translation is based on the original manuscript, to which Smithers' publication had made significant changes. In addition to adding an alternate title (Teleny, or The Reverse of the Medal), Smithers' edition also transfers the plot's action to London (originally, according to Hirsch, set in Paris) and omits a prologue. Hirsch's introduction to the 1934 Teleny claimed that Wilde had personally delivered the novel to him in a bound parcel with instructions to keep it until a friend of Wilde's in possession of Wilde's calling card arrived and requested it. None of this information can be confirmed, however. Hirsch further alleges that after one of Wilde's friends picked up the parcel, this individual then returned it to him with the identical request of holding it for another man in possession of Wilde's calling card. By this account, he suggests that Wilde used him as an intermediary to exchange the novel between his young friends before finally returning it to the author, Wilde. He explains that he knows the novel in question was Teleny because, counter to his instructions, he opened the package and read it, noting the work was penned in a combination of different handwritings, one of them Wilde's. This account is the only known source of a persistent theory that claims Teleny was written collaboratively, or 'round-robin,' including Wilde's own hand. Somehow (Hirsch does not know), the manuscript reached

\footnotetext{
${ }^{22}$ The 1958 Olympia Press edition of Teleny claims that the "date which appears on the first and only edition, 1893, may be deliberately erroneous, but several physical details tend to prove that the book was actually printed just before or very soon after that date" (6). Smithers published the 1899 edition with the help of "a mysterious figure on the Parisian erotica scene called Duringe (first name unknown)" (Nelson 2000: 291).
} 
Smithers and in 1900, after Smithers' two initial publications of Teleny, Hirsch met with him at the Exposition in Paris and discussed the changes Smithers had purportedly introduced. Hirsch further claims to have known Wilde and sold him various books including The Sins of the Cities of the Plain, which Hirsch describes euphemistically as Socratic, meaning a work of gay pornography (Hirsch 1934: 5-12).

Much has been made of Hirsch's alleged connection with Teleny although none of these details, including the identities of any of Wilde's friends, have been corroborated, nor is there any documentary evidence of Wilde's association with Teleny. Even when Hirsch was writing his introduction, the original manuscript had long been lost, making his "Notice Bibliographique" our only source for the book's history. For instance, when Nelson, in Publisher to the Decadents, suggests Wilde was the likely author of Teleny, he bases this claim on Hirsch's account (2000: 34-5, 360-1). Twenty-four years after Hirsch's edition, the Olympia Press published Teleny as no. 62 in its Traveller's Companion Series of high-end erotica, so named because of Paris' relatively lax laws on pornography, which meant travellers through Paris could purchase erotic works in France and then return home with them. ${ }^{23}$ The Olympia Press edition featured Wilde heavily in its introductory pages, claiming that "Bookdealers, collectors of erotica and Wildian [sic] students have persistently attributed to Oscar Wilde this book" and asserting they had received "additional indication that this flamboyant and poetic romance could be attributed to Wilde" along with an anonymous, rebound first edition of the work (1958: 5). The introduction goes on to give biographical information on Wilde, suggesting that Teleny "may" even be "an oniric autobiography" of Wilde, a supposed doubling of The Green Carnation (1958: 5-6).

In 1983 Peter Ackroyd reinforced these rumours with The Last Testament of Oscar Wilde, a work of fiction that imitates Wilde's literary style and imagines Wilde in 1900 Paris. Ackroyd won the Somerset Maugham Award in 1984 for this novel, in which a fictitious Wilde claims partial authorship of Teleny. The subsequent year, Gay Sunshine Press released a new edition of Teleny, a Novel Attributed to Oscar Wilde, with an introduction by its editor, Winston Leyland, insisting on Wilde's authorship of the work. John McRae wrote a similar introduction in the Gay Men's Press version of 1986, describing the work as likely a round-robin collaboration between Wilde and his young friends, as Hirsch had related. While the motivation for these publications in the 1980s was evidently a positive reclamation of Wilde as a gay icon of cultural relevance, the connection to Teleny nonetheless lacks evidential rigour and constitutes yet another possible misattribution.

Literary critical debate followed these publications with William A. Cohen's Sex Scandal (1996) which studied the similarities between Teleny and Wilde's The Portrait of Mr W. H. (1889) (Cohen 210). Alan Sinfield (1994), Mark Mitchell and David Leavitt (1997), Lisa Z. Sigel (2002), Neil McKenna (2003), Robert Gray and Christopher Keep (2006), Diane Mason (2008) and Colette Colligan (2014), among others, all reference Hirsch's account as their only source while suggesting Wilde as a collaborative author of Teleny. The list grows with the more recent OScholars special issue, edited by John McRae, who had already advocated for Wilde's authorship in his 1986 edition of Teleny. In the OScholars issue, published in 2008 but revised in 2017, McRae includes an additional fourteen articles on Wilde's putative connection with Teleny. By contrast, Jason Boyd's article, "Teleny and Wilde's Missing Gay Texts," in the OScholars addresses the lack of evidence to support Wilde's authorship, citing Teleny as part of an effort to "invent a gay corpus for Wilde [...] through forgery and misattribution." Boyd concludes that the melding of mythology and history has cemented Wilde's connection to Teleny.

\footnotetext{
${ }^{23}$ See Allsop (1966) describing the Olympia Press in relation to London.
} 
Boyd's article mentions, in fact, another text associated with Wilde that has similarly contributed to this invented corpus of erotic queer fiction. Wolfram Setz, in his introduction to another anonymously printed work of gay erotic fiction, the 2012 Valancourt Books edition of Sins of the Cities of the Plain (originally published in 1881), ${ }^{24}$ writes that "we know that Oscar Wilde read" the book as part of the "history of the novel Teleny," quoting Hirsch's account that Wilde had purchased a copy of the novel from him (vii). Setz links the two pornographic novels, Teleny and Cities of the Plain, comparing their opening scenes in order to heighten the value of the anonymous Cities of the Plain (Setz 2012: viii). At the end of Setz's introduction, he argues that the work is sufficiently valuable, thanks to its alleged connection to Wilde, that it should be printed in its original 1881 version (which includes paedophilia, transmisogyny and the use of a racist slur) rather than with the changes, fuelled by "political correctness," made in its later editions (Setz 2012: xxiv-xxv). Though Setz's comparisons of the two novels suggest it, he refrains, at least explicitly, from attributing Cities of the Plain to Wilde. Nonetheless, the value ascribed to Cities of the Plain depends primarily on Hirsch's account and Wilde's supposed contribution to Teleny. ${ }^{25}$

My approaches to these three texts, The Green Carnation, "The Priest and the Acolyte" and Teleny, have thus far addressed the authorship of each text separately. However, accounts of Wilde's life and bibliography after his death often include more than one of these works to correct the misattributions of authorship or exclude them as unworthy of discussion. Wilde's friend, Robert Sherard, in his 1906 biography, The Life of Oscar Wilde, relegates The Green Carnation to a bibliographic note, alluding to the misattribution in the The Pall Mall Gazette (1906: 456). In this biography's bibliography, which was contributed by Millard, "The Priest and the Acolyte" appears only briefly under the heading "Spurious Works" (Sherard 1906: 460), and Sherard makes no allusions to Hichens, Bloxam, or the novel Teleny. Sherard issued a supplement to his book in 1915, which he titled The Real Oscar Wilde, written largely as a response to Lord Alfred Douglas' criticism that his 1906 biography was unsatisfactory and lacked information (Sherard 1915: vii-viii). Sherard declines to mention "The Priest and the Acolyte" again in his supplementary book, but adds, in a passage speaking of Jerome K. Jerome (who had written the biting review that put an end to The Chameleon as a publication): "Wilde always declared that he objected to The Chameleon and had nothing to do with it" (1915: 355). This is not strictly true, since he contributed his aphorisms to the issue, but does reflect Wilde's attitude toward the publication during and after his libel trial. As for The Green Carnation, Sherard refers to this text with only the following lines in The Real Oscar Wilde:

It will be remembered that [Wilde] introduced from Paris that invention of some decadent horticulturalist with a penchant for chemical experiments, the green carnation, which became the vogue amongst the jeunes in London and supplied Mr Robert Hichens with a taking title for the roman à clef which made his reputation.

Sherard is careful to leave out mention of publications that, merely by including them in relation to Wilde, could harm his friend's reputation. He had no reason to dispel any rumours of Teleny's authorship at the time (indeed, he may not have been aware of the novel), but again its omission leaves Hirsch's account uncorroborated. Sherard cites Smithers in The Life of Oscar Wilde as the publisher of "The Ballad of Reading Gaol" along with other works in 1899 without any

\footnotetext{
${ }^{24}$ Hereafter abbreviated as Cities of the Plain.

${ }^{25}$ As Neil McKenna (2013) has discussed, Cities of the Plain features in its plot references to the Boulton and Park trial of 1871.
} 
mention of Teleny (1906: 414-15, 451-2). In The Real Oscar Wilde, Sherard adds only that Smithers was a publisher who helped Wilde "when nobody else would touch the poet's work" even if he "made a great deal of money out of Wilde," and whose "real trade was that of vendor of erotic literature" (1915: 344-5). Sherard seems unconcerned in either of these publications that Teleny should be associated with Wilde, and his dismissals of Bloxam and Hichens' respective books are quick and terse.

As for Millard, when first publishing his Bibliography of 1908, he devoted two pages (167-8) and eight pages $(14-20,568)$ to disproving Wilde's connection to The Green Carnation and "The Priest and the Acolyte," respectively, but did not include Teleny as a misattributed text. However, he supplies us with an interesting note, referring to the six-stanza poem misattributed to Wilde 1894, "The Shamrock," which may shed some light on Wilde's attitude toward collaborative writing:

in The Theatre, March 1895, Vol. xxv, No. 147, p. 185, Wilde explains why he does not collaborate: "Mr. Oscar Wilde has described himself as a soul revolving a cycle of masterpieces. 'And that cycle,' he said, on being asked why he did not collaborate, 'is not a cycle made for two."”

This mise en abyme of quotations is a notable instance of Wilde rejecting interest in collaborative work and could serve to undermine Hirsch's assertion that Wilde had authored Teleny "round-robin." ${ }^{26}$ We cannot confirm or deny Hirsch's statements as he printed them after Wilde's literary executor, Robert Ross, and bibliographer, Millard, were both deceased. Nonetheless, his account of Teleny's history has elevated Hirsch, once more by association with Wilde, into the annals of history where he would otherwise be less often cited.

In conclusion, these authors, publishers, scholars and booksellers exploited Wilde's fame, at times wilfully misrepresenting the facts for their own gain and at others making bold claims without conclusive evidence. The notoriety Wilde gained from his caricature in The Green Carnation may have contributed to his libel trial, but it was "The Priest and the Acolyte" that doomed him. Due precisely to its relevance in this initial trial, he would recall this text with bitterness, as he does in De Profundis, and it would thereafter follow him for at least half a century. In the case of Teleny, critical work still reinforces the image of Wilde as a writer of erotica. These texts had a pernicious effect on Wilde during his life and well after, garnering even the critical attention of renowned academics. Although some notable biographic, bibliographic and critical work over the years has laboured to disprove Wilde's association with The Green Carnation and "The Priest and the Acolyte," with respect to Teleny, the myth persists to this day. While I laud academic efforts to recover editions of Wilde's work that more explicitly express love between men, such as the 1890 uncensored edition of The Picture of Dorian Gray that first appeared in Lippincott's, counterfactual attention to misattributed texts such as Teleny suggests a fixation on Wilde's sexuality. The Labouchere Amendment that imprisoned Wilde depended on the historic hypersexualisation of queer men's relationships, an inequality that hinges on homophobia and continues in our current era. Today we must redress the longstanding cultural effect of these misattributed texts on Wilde's literary legacy.

\footnotetext{
${ }^{26}$ This does not mean he rejected all collaboration. Regarding theatre, there is a record of Wilde revising plays in production to better fit feedback from directors and actors or seeking out copy-edits of his French with Salomé. See, for instance, Evangelista (2021: 56). However, he may have taken a more individualistic approach, as implied by his statement above, with poetry or prose. He was clearly unhappy with misattributions that branded him a collaborative writer.
} 


\section{Appendix: Images}

[1] - Hichens, Robert. The Green Carnation. London: William Heinemann, 1894-e. Ross e.546. Front cover, glued to pages, typical Ledger illustration and Robert Ross Memorial Collection label. Ledger includes in pencil his date and source of acquisition for this edition (Nov 1903, Russell Library Sale, Glasgow). First page Ledger glues newspaper cut-outs, labelled by Ledger in pencil: Wilde's letter to Pall Mall Gazette printed 2 Oct 1894 refuting authorship (top) and an article on Hichens from Sunday Times 9 Nov 1930.

With special acknowledgement to the President and Fellows of University College, Oxford, for permission to reproduce this image.

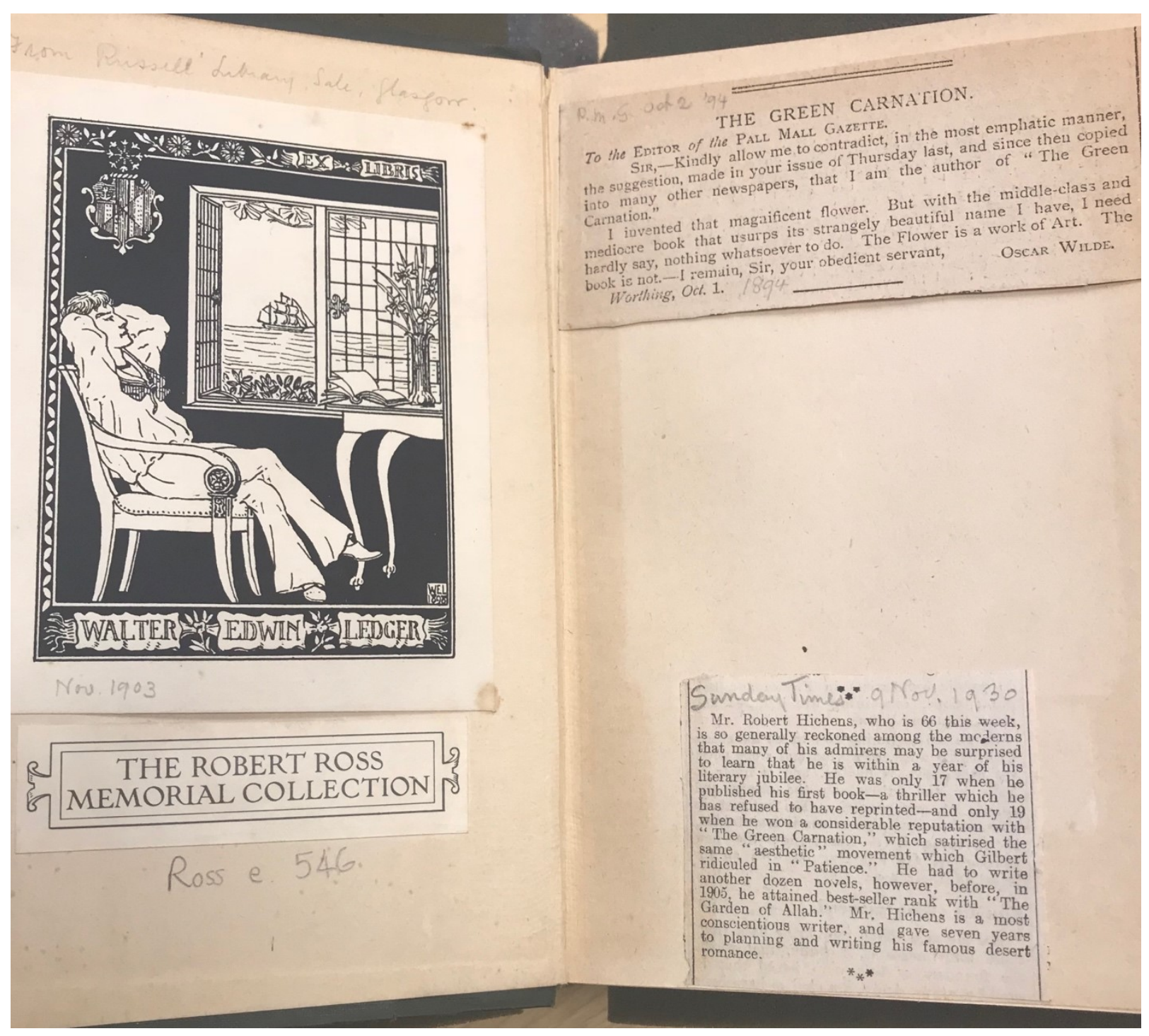


[2] - Found inside Hichens 1894-c:

Business card and sale of edition by Roy Bleiweiss, California printer.

With special acknowledgement to the President and Fellows of Magdalen College, Oxford, for permission to reproduce this image.

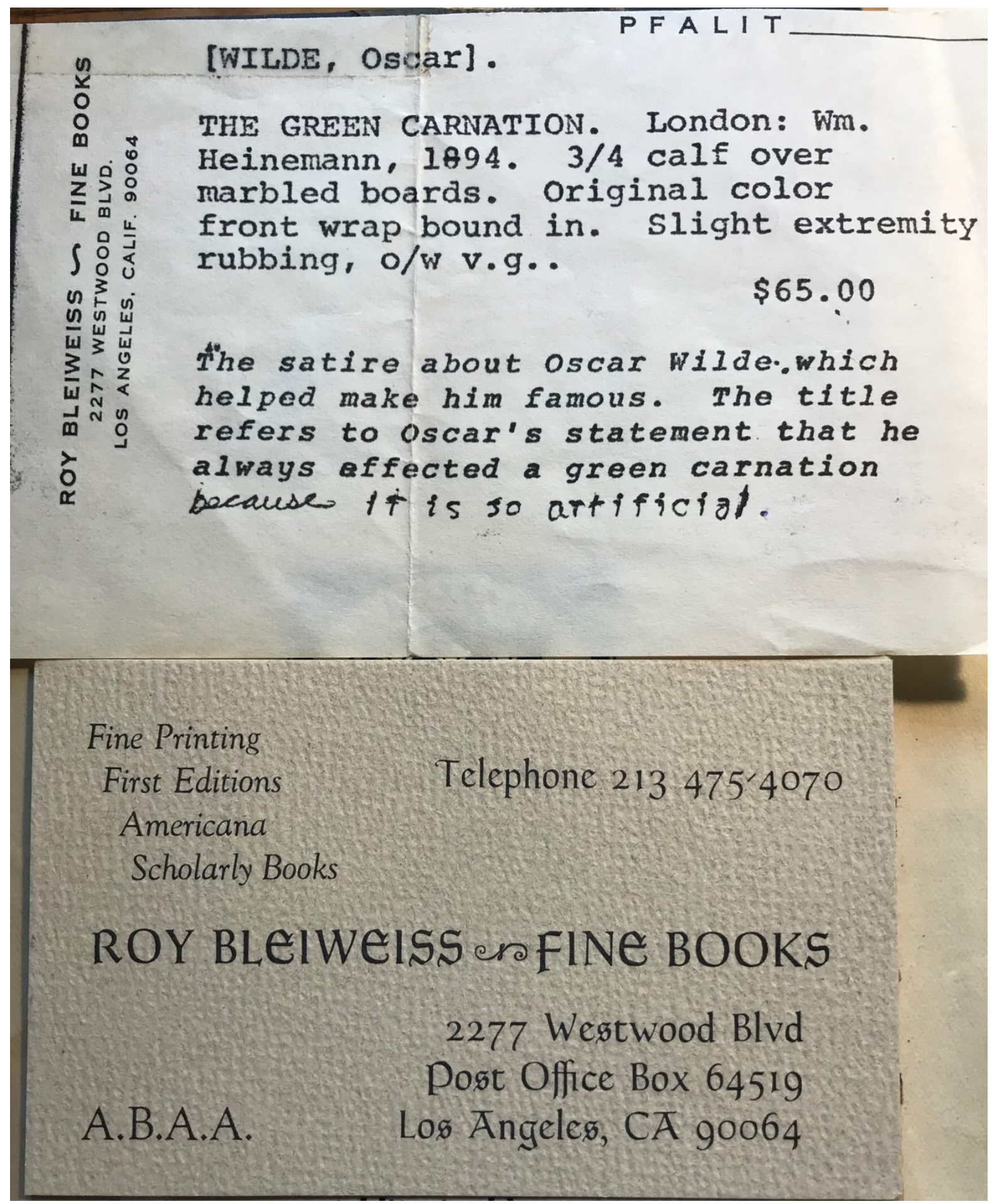


[3] - Related to Bloxam, John Francis. "The Priest and the Acolyte." The Chameleon. London: Gay \& Bird, Dec 1894, pp. 29-47. And The Priest and the Acolyte with an Introductory Protest by Stuart Mason. London: At the Lotus Press, 1907.

Ross Env.d.154.ii, "Copy of letter from J. G. Bloxam [sic] to C. Kains Jackson (November 18, 1894)," University College Oxford.

Ledger's handwriting at bottom in pencil indicates that it was sent to him by Millard on 24 Oct 1923. Millard's handwriting on left margin indicates that the "first title" of The Chameleon was to be "The Parrot or Tulip." It is unclear whether this means there were two initial titles (The Parrot or Tulip) or if The Parrot or Tulip, all together, was the intended first title.

With special acknowledgement to the President and Fellows of University College, Oxford, for permission to reproduce this image.

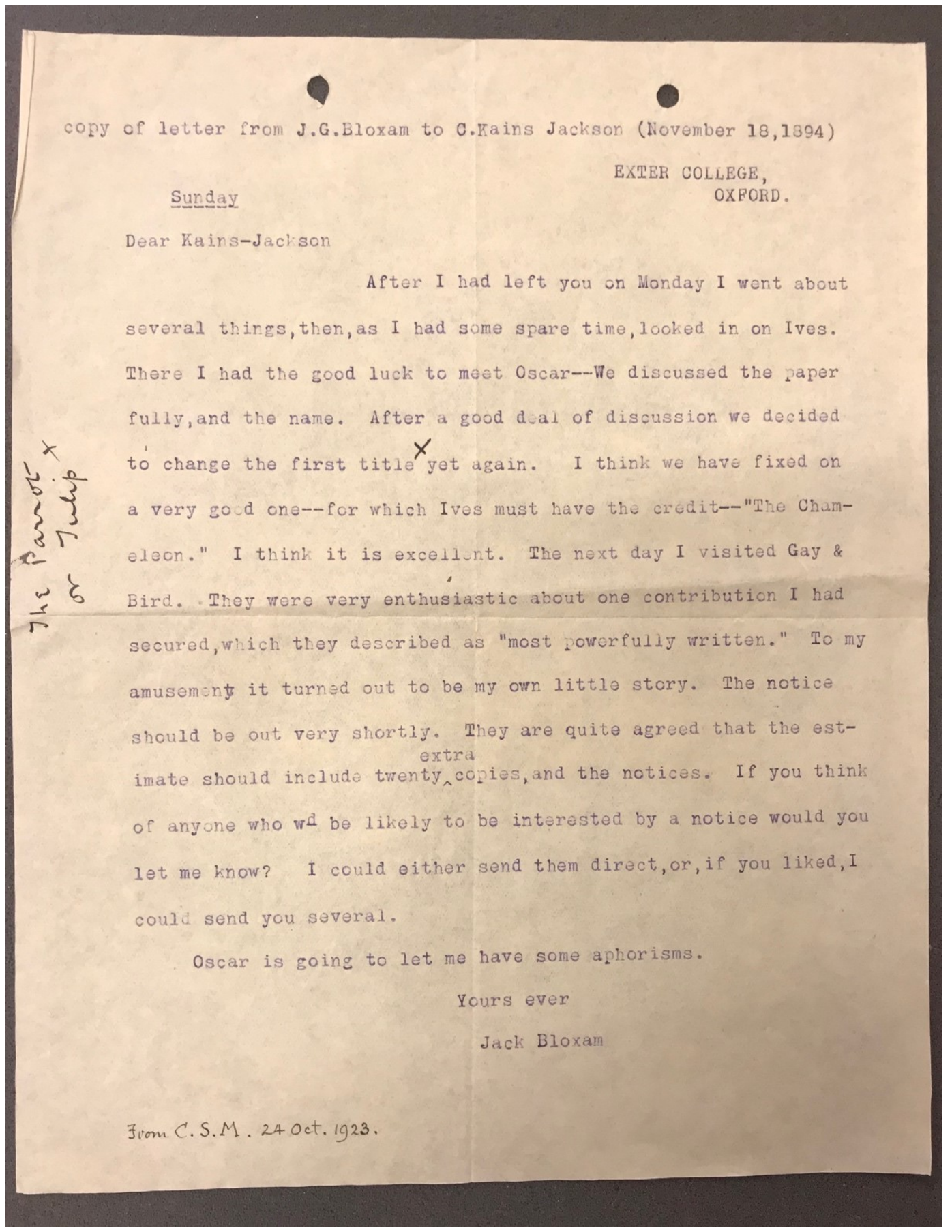




\section{Bibliography}

Ackroyd, Peter. 1983. The Last Testament of Oscar Wilde. London: Hamish Hamilton.

Allsop, Kenneth. 1966. "Pornography: Olympia Comes to Swinging London." The Spectator, 216: 29 (April): 520.

Beardsley, Aubrey. 1970. The Letters of Aubrey Beardsley, edited by Henry Maas, J. L. Duncan, and W. G. Good. London: Cassell.

Bloxam, John Francis. 1894. "Copy of letter from John Francis Bloxam to Charles Kains Jackson, 18 Nov 1894." Sent by Christopher Millard to Walter Ledger 24 Oct 1923. Ross Env.d.154.ii. Walter Ledger Collection, Robert Ross Memorial Collection. University College Library, University of Oxford.

[Bloxam, John Francis]. 1894. The Priest and the Acolyte. Privately Printed for Presentation Only. Ross e.532. Walter Ledger Collection, Robert Ross Memorial Collection. University College Library, University of Oxford.

[Bloxam, John Francis]. 1907-a. The Priest and the Acolyte with an Introductory Protest by Stuart Mason. London: At the Lotus Press. Ross e.533. Walter Ledger Collection, Robert Ross Memorial Collection. University College Library, University of Oxford.

[Bloxam, John Francis]. 1907-b. The Priest and the Acolyte with an Introductory Protest by Stuart Mason. London: At the Lotus Press. Ross e.534. Walter Ledger Collection, Robert Ross Memorial Collection. University College Library, University of Oxford.

Boroughs, Rod. 1995. "Oscar Wilde's Translation of Petronius: The Story of a Literary Hoax." English Literature in Translation, 1880-1920, 38.1: 9-49.

Boyd, Jason. 2008. "Teleny and Wilde's Missing Gay Texts." In A Special Issue of The OScholars, edited by John McRae. Published Online. http://www.oscholars.com/Teleny/boyd.htm. (Autumn), republished with corrections June 2017.

Brennan, Genevieve. 1987. "A Biographical Miscellany: Some Recent Biographies, Biographical Studies, Memoirs and Letters.” Yeats Annual, 5: 280-6. DOI: https://doi.org/10.1007/978-1-349$\underline{06841-8 \quad 29}$

Cohen, William A. 1996. Sex Scandal: The Private Parts of Victorian Fiction. Durham, North Carolina: Duke University Press. DOI: https://doi.org/10.1215/9780822398028

Colligan, Colette. 2014. A Publisher's Paradise: Expatriate Literary Culture in Paris, 1890-1960. Amherst, Massachusetts: University of Massachusetts Press.

Crowley, Aleister. 1910. Scented Garden of Abdullah the Satirist of Shiraz: Translated from a Rare Indian Ms. By the Late Major Lutiy and Another. Paris: Probsthain.

Ellmann, Richard. 1987. Oscar Wilde. London: Hamish Hamilton.

Evangelista, Stefano. 2021. Literary Cosmopolitanism in the English Fin-de-siècle: Citizens of Nowhere. Oxford: Oxford University Press. DOI: https://doi.org/10.1093/oso/978019 $\underline{8864240.001 .0001}$

Gray, Robert, and Christopher Keep. 2006. ““An Uninterrupted Current': Homoeroticism and Collaborative Authorship in Teleny." In Literary Couplings: Writing Couples, Collaborators, and the Construction of Authorship, edited by Marjorie Stone, 193-208. Madison: University of Wisconsin Press.

[Hichens, Robert]. 1894-a. The Green Carnation. London: William Heinemann (The Pioneer Series). Bodleian 256 e.8449. Bodleian Library (Stored Offsite), University of Oxford.

[Hichens, Robert]. 1894-b. The Green Carnation. London: William Heinemann (The Pioneer Series). WILDE-O.HIC.1894c.1. Magdalen College Old Library, University of Oxford.

[Hichens, Robert]. 1894-c. The Green Carnation. London: William Heinemann (The Pioneer Series). WILDE-O.HIC.1894c.2. Magdalen College Old Library, University of Oxford. 
[Hichens, Robert]. 1894-d. The Green Carnation. London: William Heinemann (The Pioneer Series). WILDE-O.HIC.1894c.3. Magdalen College Old Library, University of Oxford.

[Hichens, Robert]. 1894-e. The Green Carnation. London: William Heinemann (The Pioneer Series). Ross e.546. Walter Ledger Collection, Robert Ross Memorial Collection. University College Library, University of Oxford.

[Hichens, Robert]. 1894-f. The Green Carnation. London: William Heinemann (The Pioneer Series). Ross e.547. Walter Ledger Collection, Robert Ross Memorial Collection. University College Library, University of Oxford.

Hichens, Robert. 1896. The Green Carnation. London: William Heinemann (The Pioneer Series), (May). Bodleian 256 e.16659. Bodleian Library (Stored Offsite), University of Oxford.

Hichens, Robert. 1949. The Green Carnation. London: Unicorn Press.

Hirsch, Charles. 1934. "Notice Bibliographique extraite des notes et souvenirs d'un vieux bibliopole." Teleny: Étude physiologique, traduit de l'anglais sur le manuscrit original révisé par l'auteur, 5-12. Paris: Privately Printed for members of the Ganymède Club de Paris.

"Just Out. Complete. The Life of Oscar Wilde as Prosecutor and Prisoner." London: Published for the Proprietors, at 43 Stanhope St, Clare Market, 6 to 11 April 1895. Ross d.101. Robert Ross Memorial Collection. University College Library, University of Oxford.

Kingston, Angela. 2007. Oscar Wilde as a Character in Victorian Fiction. New York: Palgrave Macmillan.

Ledger, Walter Edwin. Ross Bibliographic Folder 7: Great Britain: Appendix, The Priest and the Acolyte. Walter Ledger Collection, Robert Ross Memorial Collection. University College Library, University of Oxford.

Mackie, Gregory. 2004. "Publishing Notoriety: Piracy, Pornography, and Oscar Wilde." University of Toronto Quarterly, 73: 980-90.

Mackie, Gregory. 2019. Beautiful Untrue Things: Forging Oscar Wilde's Extraordinary Afterlife. Toronto: University of Toronto Press. DOI: https://doi.org/10.3138/9781487516260

Mason, Diane Elizabeth. 2008. The Secret Vice: Masturbation in Victorian Fiction and Medical Culture. Manchester: Manchester University Press. DOI: https://doi.org/10.1086/652254

McKenna, Neil. 2003. The Secret Life of Oscar Wilde. London: Century. DOI: https://doi.org/10.14288/ clogic.v11i0.191900

McKenna, Neil. 2013. Fanny and Stella: The Young Men Who Shocked Victorian England. London: Faber and Faber.

McRae, John (ed.). 2008. Teleny. A Special Issue of The OScholars. Published Online. https://oscholarsoscholars.com/special-issues/teleny-revisited/. (Autumn), republished with corrections June 2017.

[Unpublished] Millard, Christopher Sclater. 1905. "Letter to Walter Ledger. 27 Apr 1905." MS Ross 13/1. University College Library, University of Oxford.

[Unpublished] Millard, Christopher Sclater. 1906. "Letter to Walter Ledger. 3 Mar 1906." MS Ross 13/1. University College Library, University of Oxford.

[Unpublished] Millard, Christopher Sclater. 1914. "Letter to Walter Ledger. 28 Apr 1914." MS Ross 13/1. University College Library, University of Oxford.

[Unpublished] Millard, Christopher Sclater. 1920. "Letter to Walter Ledger. 31 Mar 1920." MS Ross 13/1. University College Library, University of Oxford.

Mead, Donald. 2015. "Oscar's Finances: The Pillage of the House Beautiful. Chapter Six: The Bankruptcy Sale." The Wildean, 47: 38-55.

Mendes, Peter. 1993. Clandestine Erotic Fiction in English 1800-1930: A Bibliographic Study. London: Routledge. DOI: https://doi.org/10.4324/9781315260112 
Millard, Christopher Sclater [Mason, Stuart]. 1967. Bibliography of Oscar Wilde. London: Bertram Rota.

Mitchell, Mark and David Leavitt (eds.). 1997. Pages Passed from Hand to Hand: The Hidden Tradition of Homosexual Literature in English from 1748 to 1914. Boston: Houghton Mifflin.

Murray, Isobel. 1996. "The Bibliographies of Oscar Wilde.” The Wildean, 8: 53.

Nelson, James G. 2000. Publisher to the Decadents: Leonard Smithers in the Careers of Beardsley, Wilde, Dowson. Appendix by Peter Mendes. University Park, Pennsylvania: Pennsylvania State University Press. DOI: https://doi.org/10.2307/4053258

Roditi, Edouard. 1947. Oscar Wilde. Norfolk, Connecticut: New Directions.

"Second Edition. Just Out. The Life \& Doings of Oscar Wilde, Further Startling Developments." London: Published for the Proprietors, at 43 Stanhope St, Clare Market, April 1895. Ross d.102. Robert Ross Memorial Collection. University College Library, University of Oxford.

Setz, Wolfram (ed.). 2012. Sins of the Cities of the Plain. London: Valancourt.

Schroeder, Horst. 2002. Additions and Corrections to Richard Ellmann's Oscar Wilde, 2nd ed. Braunschweig: Privately Published.

Sherard, Robert Harborough. 1906. The Life of Oscar Wilde. London: T. Werner Laurie LTD.

Sherard, Robert Harborough. 1915. The Real Oscar Wilde; To be used as a Supplement to, and in Illustration of "The Life of Oscar Wilde." London: T. Werner Laurie LTD. Ross d.116. Robert Ross Memorial Collection. University College Library, University of Oxford.

Sigel, Lisa Z. 2002. Governing Pleasures: Pornography and Social Change in England, 1815-1914. New Brunswick, New Jersey: Rutgers University Press.

Sinfield, Alan. 1994. The Wilde Century: Effeminacy, Oscar Wilde and the Queer Moment. London: Cassell.

Stratford, John. 1995. "The Bibliographies of Oscar Wilde." The Wildean, 47: 21-6.

Wilde, Oscar. 1894. "The Green Carnation." The Pall Mall Gazette, 9212, London. British Library Newspapers, Part I: 1800-1900. GALE.

[Wilde, Oscar, attrib.] 1958. Teleny, or The Reverse of the Medal. Paris: Olympia Press.

[Wilde, Oscar, attrib.] 1984. Teleny, A Novel Attributed to Oscar Wilde, edited by Leyland Winston. San Francisco: Gay Sunshine Press.

[Wilde, Oscar and Others, attrib.] 1986. Teleny, edited by John McRae. London: Gay Men's Press Publications.

Wilde, Oscar. 2000. The Complete Letters of Oscar Wilde, edited by Merlin Holland and Rupert Hart-Davis. London: Fourth Estate.

Wilde, Oscar. 2005. The Complete Works of Oscar Wilde: Volume 2, De Profundis, edited by Ian Small. 